\title{
RADIOACTIVE CEMENT OF PMMA AND HAP-Sm-153, Ho-166, OR RE-188 FOR BONE METASTASIS TREATMENT
}

\author{
CIMENTO RADIOATIVO DE PMMA E HAP-Sm-153, Ho-166 OU \\ RE-188 NO TRATAMENTO DE METÁSTASES ÓSSEAS
}

\author{
Carlos Julio Montaño ${ }^{1}$, Tarcisio Passos Ribeiro de Campos $^{1}$ \\ 1. Department of Nuclear Engineering, Laboratório Núcleo de Radiações lonizantes, Universidade Federal de Minas Gerais (UFMG), Belo Horizonte, MG, Brazil.
}

\section{ABSTRACT}

Polymethylmetacrylte (PMMA) is used in the fields of dentistry and biomedicine as a constituent of bone cements. Hydroxyapatite (HAp) is a bioceramic produced naturally in the bones. PMMA and HAp are fundamental constituents in the preparation of bone cements. Bisphosphonates have also been used as radiopharmaceutical in dental implants and nuclear medicine, or as palliative systemic treatment for pain reduction in bone metastasis. Vertebroplasty and kyphoplasty are bone cement-based techniques used in orthopedics, being minimally invasive procedures with low risks of infections, applied in osteoporosis and high-impact fractures. Recently, Núcleo de Radiações Ionizantes da Universidade Federal de Minas Gerais proposed a synthetic composite of M-HAp with a metallic nuclide $M$. After irradiation, M-HAp was added to PMMA, compounding a radioactive bone cement that can recover bone body stabilization, pasting microfractures and recomposing the anatomy and functionality of the affected parts by the compression of bone metastases, with possible pain reduction through quick radiation-induced decompression. Computational dosimetric models, and the synthesis and characterization of bioceramics that incorporate Re-188, Ho-166, or Sm-153 have demonstrated the benefits of these biometrics as promising alternative therapies, mainly from their ability to maintain the ionization in the bone structure, thereby sparing the spinal cord. This article presents a review on this topic. Level of Evidence V, Expert Opinion.

Keywords: Cement. PMMA. Hydroxyapatite. Vertebroplasty. Kyphoplasty. Radioisotopes.

\section{RESUMO}

Polymethylmetacrylte (PMMA) é um composto utilizado na indústria e desde os anos 80's também tem sido empregado nas áreas odontológica e biomédica como constituinte de cimentos ósseos. A hydroxyapatite (HAp) é uma biocerâmica produzida naturalmente nos ossos. Esses dois componentes são constituintes fundamentais no preparo de cimentos ósseos. A síntese artificial de HAp pode ser feita pelo método sol-gel. Bifosfanatos tem também sido utilizado na odontologia em implantes dentários e na medicina nuclear, como radiofármaco ou no tratamento paliativo sistêmico de redução de dor das metástasis ósseas com ${ }^{153} \mathrm{Sm}$ -EDTPM. A Vertebroplastia e Cifoplastia são técnicas empregadas na ortopedia utilizando o cimento ósseo, sendo procedimentos minimamente invasivos de baixo risco de infeções, aplicadas em osteoporose e fraturas de alto impacto. Recentemente, no Grupo de Pesquisa NRI - Nucleo de Radiações Ionizantes/UFMG, foi proposto um compósito de M-HAp com nuclideo metálico M incorporado na matriz, que após ativado é adicionado ao PMMA constituíndo um cimento ósseo radioativo que pode recuperar a estabilização o corpo ósseo, colando microfraturas, recompondo a anatômia e funcionalidade de peças afetadas pela compressão das metástases ósseas com possível redução de dor pela rápida descompressão induzida pela radiação. Modelos dosimétricos computacionais, sintese e caracterização destas biocerâmicas incorporando Re-188, Ho-166 ou Sm-153 tem indicado benefícios radioterapêuticos promissores, podendo se tornar uma alternativa para radioterapias convencionais, principalmente por conter a dose absorvida na estrutura óssea, por exemplo no corpo da vertebra poupando a medula espinhal. O presente artigo apresenta uma revisão sobre o tema. Nível de Evidência V, Opinião do Especialista

Descritores: Cimento ósseo radioativo. PMMA. HAp. Vertebroplastia. Cifoplastia. Radioisótopos.

Citation: Montaño CJ, Campos TPR. Radioactive cement of PMMA and HAP-Sm-153, Ho-166, or RE-188 for bone metastasis treatment. Acta Ortop Bras. [online]. 2019;27(1):64-8. Available from URL: http://www.scielo.br/aob.

\section{INTRODUCTION}

At the present time, there are few clinical procedures to meet the countless cases of cancer in advanced stages with confirmed and widespread metastases. These represent critical clinical situations where the disease spreads from in situ for loco-regional sites, toward the entire human body, becoming systemic and affecting organs and skeleton. At that stage, medical science does not bring hope to the patients, and death can happen weeks or months after

All authors declare no potential conflict of interest related to this article.

Study was conducted at the Universidade Federal de Minas Gerais (UFMG), Belo Horizonte, MG, Brazil. Correspondence: Tarcisio PRCampos. Escola de Engenharia, Depto. Eng. Nuclear, Bloco 4, Sala 2285, Av. Antônio Carlos, 6627 Belo Horizonte, MG, Brasil. $31270-901$. tprcampos@yahoo.com.br 
confirmed a diagnosis of disseminated metastasis, as a consequence of the morbidity of this disease. Bone involvement by micro tumors produces trauma that generate huge intensity of pain. In most cases the pain is severe due to several secondary metastatic processes produced by the micro-fractures in the bone structure, being recommended by clinical staff introducing palliative measures for pain reduction. In this clinical picture, it is understandable that the disease has already progressed to a stage of irreversibility and it is not likely a full recovery of the patient. Morphine is of the common use, among other medications; even if such drug doesn't act on recovering induced compression fractures produced by cancerous tumors metastatic. ${ }^{1}$

There are possible interventions by the radiation therapy (RT), chemotherapy or surgical procedures. Although there is a great limitation of beam portals and of bone target volume at RT. Teletherapy brings deleterious effects because it is inevitable the exposition of other vital organs or regions of the body to ionizing radiation; especially considering the clinical condition and the patient's weakened immune system.

In the 80ties, Harrington K.D. proposed the use of polymerized methyl methacrylate for stabilization of vertebral bodies with fractures or dislocations induced by bone metastases. Metastasis induces an increase in the internal pressure of the vertebral body and compromise the patient care. ${ }^{2}$ A solution was presented for pain reduction but the exothermical effects provided by the polymerization of methyl methacrylate became a part of the side effects of the procedure. ${ }^{2,3}$ In accordance to Harrington, on the post-surgery of 13 to 14 pacients, an improvement in pain was observed with the stabilization of the spine with the use of metyl-methaclylate. However, external radiation therapy was held in addition. The source of radiation was external to the body and the restorative cement was used only to improve stability of the vertebral body. The clinical benefits with the use of PMMA extended from 13 to 45 months the postoperative procedure. In the $90^{\text {th }}$, this cement was used as a mechanism for the stabilization of the vertebral bodies. In cases of bone metastasis, the irradiation therapy provided by linear accelerators complements the treatment using Intensity Modulation Radiation Therapy (IMRT). IMRT proposes dose reduction in adjacent tissues; ${ }^{4}$ however, it involves greater complexity including multiple fields to limit the prescribed dose at the target volume. In other procedures, the use of radioisotopes as rhenium-186 or stroncium-89, were considered with intravenous application providing an imparted absorbed dose in bone structure covering a broader systemic distribution, but with a clinical effect in favour of pain reduction. However, the restorative cement of the vertebral bodies was still the option held. ${ }^{5}$

In 1987, the vertebroplasty and kyphoplasty were introduced. Those techniques considered using the restore bone cement based on the volume of the affected vertebral bodies and the metastasis-type classification, well documented in the literature. It is worth mention that Harrington K.D introduced this classificaion in the early 80 's. ${ }^{6.7}$ Similat to the palliative IMRT, the association of radiation therapy with vertebroplasty and kyploplasty procedures had the goal of reducing the symptoms of the bone metastases. In the early $90^{\text {th }}$, the Sm-153-EDTMP systemic therapy was investigated. The intraveneous use of Sr-89 and Re-186 produced a toxic effect holding high spinal cord neurological deficits due to an effect of demyelination. ${ }^{8}$ In 2006, a new material was introduced by the NRI research group - Nucleo de Radiações lonizantes at UFMG, namely Radioactive Bone Composite including polymetylmetacrylate (PMMA) and an aggregate of hydroxyhepatite incorporating a radioactive metal in its structure. ${ }^{9-12}$ Despite all the research and investiment in the radioactive cement in the NRI/UFMG, it is being a challenge the improvement of biocomposite affinity on the bone structure, the expantion of the absorbed dose distribution in situ, and the generation of knowledge in the properties of the radioactive cement and its interactions with the metastasis-bone interface.

The present review addresses these issues and describes this possible radiotherapic treatment represented by the interstitial insertion of an amount of radioactive cement within a bone structure, in particular in the thoracic vertebrae body. The cement contains a ceramic composite that maintains a radioisotope beta-emitter inserted into its amorphous structure. It can hold a spatial distribution such that ionizing radiation is spread and absorbed into the desired metastatic lesions, preserving the healthy adjacent tissues, avoiding possible invasive surgical procedures, and reducing indiscriminate radiation exposures. ${ }^{13}$

\section{Some cancer epidemiological data in Brazil}

Cancer data on a global scale, according to Globocan 2018, report that in the world about of 18 million people per year get sick because of cancer, holding the larger impact on women with breast cancer (24.2\%), colon and rectum (9.5\%), lung (8.4\%), uteri cervix (6.6\%); and, on men, with prostate (13.5\%), colon and rectum (10.0\%), liver (6.3\%), lung (14.5\%), stomach (7.2\%); among others. ${ }^{15}$ Our country is no stranger to this problem since the incidence of breast cancer has reached $29.5 \%$, with 59,700 new cases in 2018-2019. ${ }^{14}$

Breast cancer has produced the greatest female cancer mortality in Brazil for several decades, with the incidence increasing significantly every year. Statistics have shown that, in 1986 when the Sistema Único de Saúde-SUS was stablished, $12.8 \%$ of women died due to cancer that year, and breast cancer was the leading cause of these deaths. In 1998, the total number of cases of breast cancer was about 32,000 whose $66 \%$ of women died. At 2014, the southeastern region of the country showed the highest number of registered cases followed by the Northeast and South of which $60 \%$ of deaths occurred due to breast cancer. ${ }^{16}$ Studies showed that the common standard metastatic conditions are the visceral (liver, lung or pleura and breast) but in smaller proportion there is bone metastases, and consequently the possibility of application of percutaneous technique with bone cement.

Regarding the cancer incidence, it is urgent to develop protocols for addressing the problems that affect patients with dissiminated cancer in order to expand the action of the SUS in whole contry. Since breast cancer is the most likely to manifest metastasis both in thoracic region as in other parts of the body, new treatment methods need to expand, improve and be disseminated to increase the quality of life of patients and achieve a complete remission, even in clinical unfavorable situations. Even in regions with lower concentration of population, the numbers of cases are in smaller proportion, but they are still having a high impact and increasing incidence. ${ }^{16}$ In addition, it is desirable the development and application of therapies that produce a lower operational cost, being minimal invasive, in order to reduce the risk of infections for patients whom in most cases are immune depleted.

The study of cements for treatments of bone metastases contains a number of clinical and technical knowledge that must be considered and detailed, at the time that new protocols are developed in the frame of the innovation of palliative treatments; in which the use of radioactive bone cement is promising.

Anatomic classification and structural mechanical functions of the bone tissue

When James Weinstein in 1989 established an anatomical classification of the regions of the vertebral body, it was possible to identify the most frequent metastases types in each of the regions and thus specify the most difficult to treat by their proximity to the spinal cord. This anatomical distribution basically presents four regions, in which regions III and IV, laid down in front of the spine, 
are those that attend a percutaneous procedure by inserting a bone acrylic. ${ }^{3,13,17}$ Those two regions due to your nature have the greatest tendency to collapse as a result of the metastases because those support a greater natural compression of the skeletal structure. In the long bones, abnormalities (tumors or metastases) are frequent in the metaphyseal region. Such tissue is a kind of intermediary tissue between the spongy tissue (epiphyses) and mature or osteolytic tissue (diaphyses).

The mechanical properties maintain an important role in the study of the skeletal system. Understanding your conformation and type of structures that are part of your composition are keys to propose possible substitute materials. Such material must have greater affinity for bone tissue, represented by the fibrils of collagen, which is the substance that composes most of the bone tissue, and the other substances as apatitas carbonate crystals and all proteins that are not collagens.

\section{Bone diseases, types of metastasis}

There are different bone neoplasms that degenerates the bone tissue being classified as benigns or malignants. Sarcomas are malignant neoplasms that manifestate in different regions of the bone tissue. However, the most relevant anomalies are especially those produced by the metastasis that represents the dissimination process of different cancer cells, via vascular or lymphatic systems, toward the bone bodies, where the clonogenic process is kept inside the bone. Bone metastasis is present in $80 \%$ of the loco-regional breast carcinoma. ${ }^{20}$

\section{Bone cement, structure and composition}

Several biomaterials have been proposed for the replacement of bone tissue or for the reconstituion of parts of them that are missing. Such material is able to add and paste parts of the structural bone. The fractures can be filled by acrylic PMMA cement, or even can be recomposed with biocompatible substances implanted as arrays as bioceramics of calcified phosphates. ${ }^{21}$ Such bioceramics participate in the processes of adsorption and reabsorption of calcium, which manifest in biological phenomena such as the osteogeneses present in the regeneration of bone tissue in destroyed regions. ${ }^{21}$ There are several studies in biophosphanates, among which we can highlight the hydroxyapatite (HAp). HAP presents itself in the natural bone with $69 \%$ of mass weight. Cristals of HAps are also distributed in the fiber matrix of collagen, which represents $20 \%$ of the bone tissue. $^{13}$ Since this substance is a natural bone constituent, HAp mixed with PMMA was proposed as biomaterial, reaching a great response of osteoblasts adhesion. ${ }^{22.23}$

\section{Therapeutic treatment and percutaneous procedures}

The vertebroplasty is a percutaneous minimally invasive procedure developed for surgery in spinal bone. ${ }^{1}$ The procedure is performed by inserting acrylic in the fracture of the vertebral body. Such acrylic was developed and described for the first time in France in 1987.,13 This procedure makes use of a larger gauge needle to puncture the fractured vertebral body, where it is inserted the bone cement, stabilizing and reinforcing the bone structure to recover its original configuration. The technique was first used in the treatment of vertebral hemangiomas and subsequent in fractures of compression in osteolytic metastases and osteoporoses. ${ }^{17}$ The technique has also been used for the treatment of osteoporosis and pathologic fractures by compression.In the United States, the most of the applications are related to osteoporosis. The literature reports a satisfactory rate of $90 \%$ pain reduction in metatatic sites. Besides, the percutaneous kyphoplasty procedure differentiates from the vertebroplasty technique. In Kiphoplasty, a balloon is inserted into the collapsed vertebral body, and the balloon is inflated prior to insertion of the bone cement. ${ }^{3}$ in this case, the bone cement is contained internally by the surface of the balloon. Figure 1 illustrates some associated instruments to vertebroplasty.

Both techniques, using polymethylmethacrylate (PMMA), improve the stability of the vertebra and attempt to retrieve the original anatomical nature. The indications of vertebroplasty and kyphoplasty are to the treatment of tumors in the spine bone and the thoracic pain reduction from fractures of the lumbar vertebral bodies in patients with cancer. The contra indications are the epidural compression of the nervous system and the absence of recognition of symptomatic sites. Other contraindications are on coagulopathy and local infections. ${ }^{24}$ One of the possible failures of these techniques that make use of restorative cements is the cement extravasation, although it is an unlikely phenomenon.

The treatments are completed with teletherapy in the metastatic lesions that can be prescribed by IMRT (Intensity Modulated Radiotherapy) or IGRT (Image-guided Radiotherapy). These procedures provide a single high dose application, assuming a no-split dose-protocol with absorbed doses limited. This procedure is scheduled after surgical removal of the tumor or metastic lesions. The IMRT is radiotherapy where there are a suitable modulation of beam-intensities and the full covering of the target region, accompanied by the reduction of dose in the surrounding healthy tissues. Some anatomical and physiological unique aspects of the vertebral
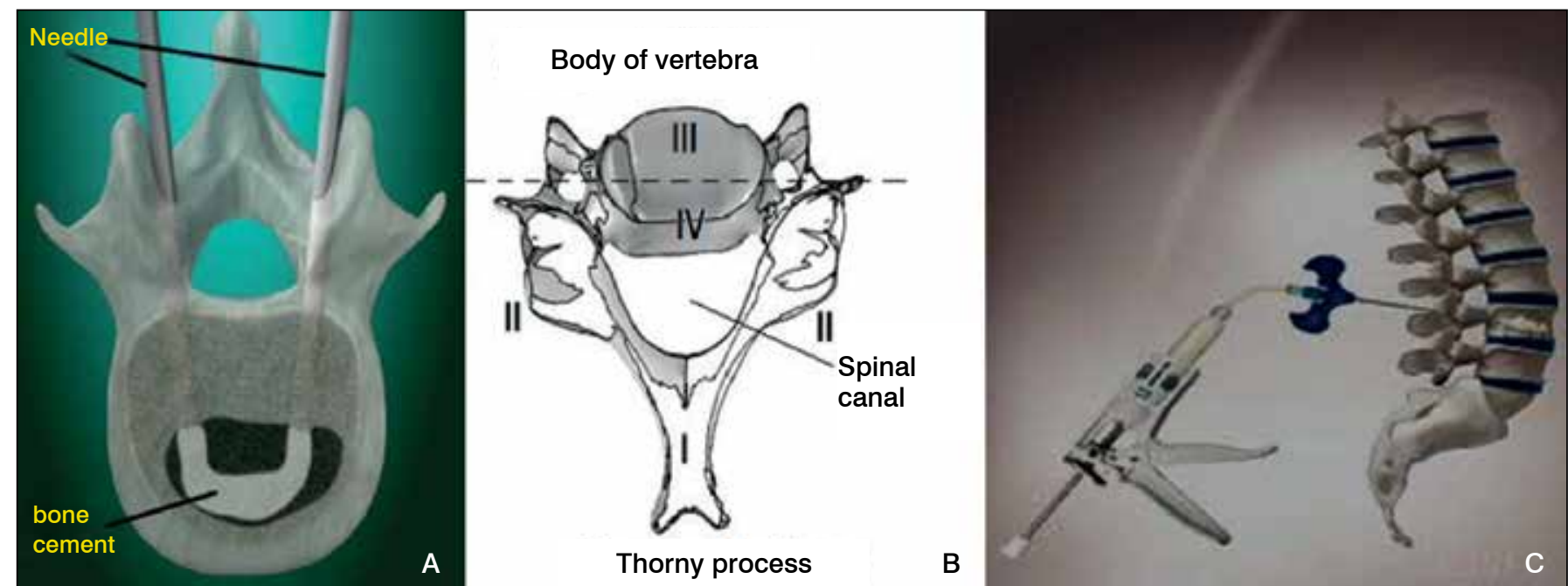

Figure 1. Minimal invasive procedures: anatomical position of vertebrae. (A) Vertebroplasty; (B) anatomical regions of the vertebrae according to Harrington; (C) Kit and Vertebroplasty simulation. ${ }^{3}$ 
body are of relevance. ${ }^{4}$ The RT procedure's restriction is on the low dose tolerance of the spinal cord to a no-fractionated regime. In fact, the recommended dose on the body of the vertebra must be greater than the tolerance dose of marrow, which produces a greater commitment for late neuro effects due to demyelination of the tissues of the nervous system, since its radiosensibility.

Systemic therapies are part of combined procedures for treatment of metastases. Chemotherapy, combined or mono, involves a set of drugs that depend on the histology of the tumor and of its quimio sensibility. In general, the drugs used in prostate or breast metastasis are cytotoxic agents with low specificity. The biophosphanates are used as pain reductions in cases of acute and moderate pain, contributing in the resorption of bone tissue removed by osteoclasts, and shrinking the tumors associated with osteolysis. ${ }^{18}$ Studies in biophosphanates have shown a significant rate decrease of fractures of the skeletal system. The systemic drugs with intravenous administration containing strontium-89 and rhenium-186 may be used as systemic radiation therapy of the spine, being an alternative to treat pain. ${ }^{25}$

In 2008, Sm ${ }^{153}$-EDTMP was incorporated into kyphoplasty; ${ }^{7,26}$ however, limited into a balloon. Consequently, the applied dosimetry was neglegible. ${ }^{27}$ At the kyphoplasty percutaneous procedure; the $\mathrm{Sm}^{153}$-EDTMP was incorporated with the PMMA. The EDTMP is a biphosphanate that carries the $\mathrm{Sm}^{153}$ radioisotope by coordinating connection forming a complex., ${ }^{7,26}$ The advantage of using a radioisotope is in optimizing the distribution of the effective dose, which may provide the prescribed dose predefined in other radiation therapies. The $\beta$-emitters P-32, Y-90, Ho-166 are included on the radioisotope group useful for these palliative treatment. In addition, those beta-particles emitters hold lower range in trabecular tissue; and, consequently, the spatial dose distribution is contained in the bone region, unlike with Tc-99, which is a gamma emissor. ${ }^{27}$

Radioactive material production, vertebral model and computational dosimetry

Studies conducted in our laboratory NRI-Nucleo de Radiações lonizantes, by Drs. Rodrigo D'alessandro de Macedo, Márcia Flavia Silveira, Blanda Alves Donanzam, and Dr.llza Dálmazio, together with the present authors, provided the developed of the radioactive cement PMMA + M HAp, being M a $\beta$-emitter radioisotope ligand to the matrix of hydroxyapatite, and so providing a radioactive cement. 9-12 The synthesis of the bioceramic crystals of hydroxyapatite linked to the cold metal (cold = non-radioactive) was done using sol-gel technique..$^{9-12}$

Initially, the cement was developed containing small amoung of mass of HAp in relation to the mass of the PMMA. ${ }^{9}$ In these conditions, the material presented a very rapid polymerization. In addition, the biomechanical properties match with those of the compact bone. Such inorganic structure hinders the calcium trades by absorption and reabsorption present in the process of restoration of natural injured bone.

The M-HAp crystals exposed to thermal and epithermical neutron fluxes, about $2.6 \times 10^{12}$ and $2.8 \times 10^{11}$ neutron $\times \mathrm{cm}^{-2} \times \mathrm{s}^{-1}$, respectively, in an irradiation time of $8 \mathrm{~h}$, provided specific mass activities more than enough to control bone metastasis. The ${ }^{188} \mathrm{Re},{ }^{166} \mathrm{Ho}$ and ${ }^{153} \mathrm{Sm}$ nuclides were chosen, mainly due to the easiness of the chemical synthesis, the low cost of the reagents, as well as the radiodosimetric advantages produced by $\beta$-emitters. There were good spatial dose distributions in the vertebrae body and a rapid accumulation of dose, due to the short half-lives of nuclides; as well a negligible dose on spinal cord. ${ }^{10.11}$

The dosimetry of bone cements was demonstrated by studies in computational models. ${ }^{10,11}$ In Figure 2, the employed computational model of the spinal cord is depicted. The model was developed with the aid
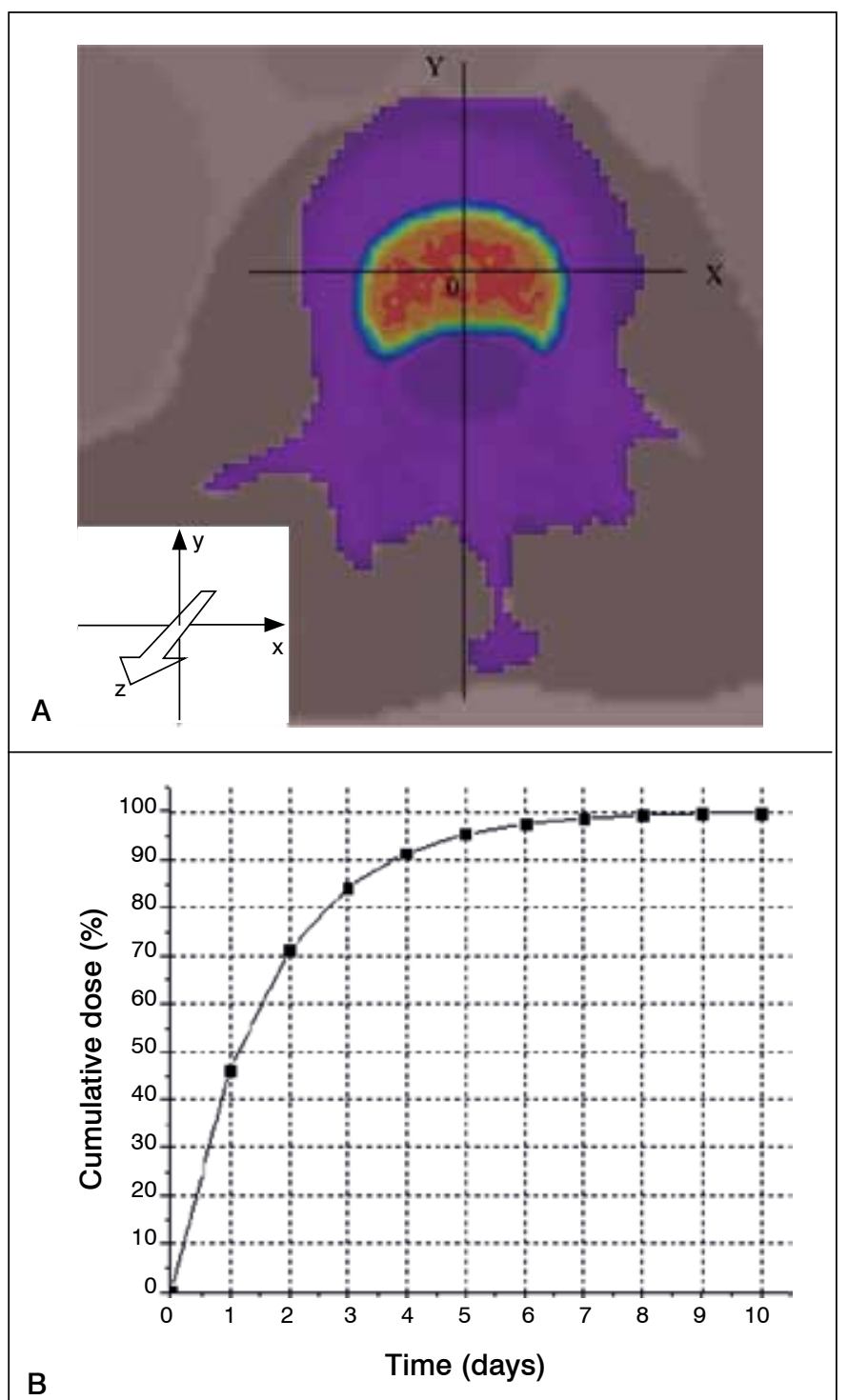

Figure 2. Computational model with MCNP5/Siscodes - BED. (A) vertebral model of the spine and isodose distribution. (B) accumulated dose curve for cement bound with Ho-166. ${ }^{11}$

of the SISCODES program and the transport of particles was made in code Monte Carlo N-Particle version 5 (MCNP5). The absorbed dose and the BED (Biological Effective Dose) in the body of the vertebrae and spinal cord have been assessed. ${ }^{22,23} \mathrm{AHAp}+\mathrm{Ho}^{166} \mathrm{HAp}+\mathrm{PMMA}$ cement, containing one milligram of $\mathrm{Ho}^{166} \mathrm{HAp}$, provided a BED of 102 $\mathrm{Gy}_{10}$, considering a activity of $32.5 \mathrm{MBq}$. In this procedure, there was a 10 -folds reduction in spinal cord dose compared to an external beam radiotherapy procedure using IMRT or IGRT.

Figure $2 \mathrm{~b}$ depicts a representation of the accumulated absorbed dose in function of time produced by the proposal radioactive concrete with Ho-166, whose total dose reaches $100 \%$ after a period of 10 days. On ongoing research, the bone cement is being synthesized with Sm-152 and activated in Sm-153. The half-lives of Ho-166 is $26.8 \mathrm{~h}$ and Sm-153 $46.50 \mathrm{~h}$, and both are beta emitters. The specific activity obtained for M-HAp, irradiated in the IPR1/

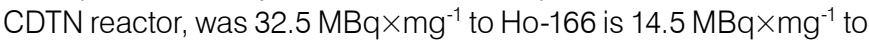
$\mathrm{Sm}-153$. The larger half-life of Sm-153 can encourage management of distribution of this radiopharmacal to the hospitals, improving the cost-benefit ratio. 


\section{FINAL REMARKS}

Radioactive bone cement offers promising features for the treatment of bone metastasis in situ. However, finding the optimum conditions of application represents a challenge. Possible biomedical studies must be developed involving radio-toxicity, cytotoxicity, dosimetry, radiobiology, clinical response, among others. In an application, one can expect a good viscocity, a suitable curing time, high porosity after curing, and permeability to bone cells that progressively are able to regrow after the end of the radiation exposure. The cement must reach the regions of metastatic lesions that usually found in the trabecular bone, where the fractures are not of high impact. In these cases, the pain is associated with the compression of the existing micro tumors and presence of possible microfractures. ${ }^{25}$
The affected bone tissue has natural porous and have less resistant than compact one, showing constant regeneration. In these sites, other natural biological features are present, such as medular cell diffusions, angiogenesis and revascularization. ${ }^{29-30}$ The future goal has been to transform the radioactive cement post-exposure more nature with characteristics of the porous bone tissue. The procedure should be optimizing avoiding unwanted effects such as thermal necrosis, produced by polymerization of PMMA where local temperatures can reach up to $110^{\circ} \mathrm{C}$, and chemical necrosis, produced by excess of chemicals that induce polymerization. The ideal is to have a composite that deals with the metástasis in situ and produces a porous matrix that does not stop the natural bone regeneration processes.

AUTHORS' CONTRIBUTIONS: Each individual author contributed significantly to the development of the manuscript. TPRC (0000-0003-1476-3474)* and CJM (0000-0001-7125-9982)* were the main contributors in the writing of the manuscript. They facilitated the development of the bibliographical research, reviewed the manuscript, and contributed to the final manuscript. *ORCID (Open Researcher and Contributor ID).

\section{REFERENCES}

1. Horn E, Henn JS, Lemole GM, Hott JS, Dickman CA. Thoracoscopic placement of dural-rod instrumentation in thoracic spinal trauma. Neurosurgery. 2004; 54(5):1150-4.

2. Harrington KD. The use of methylmetacrylate for vertebral-body replacement and anterior stabilization of pathological fracture-dislocations of the spine due to metastatic malignant disease. J Bone Joint Surg Am. 1981;63(1):36-46.

3. Georgy BA. Metastatic Spinal Lesions: State-of-the-Art Treatment Options and Future Trends. Am J Neuroradiol. 2008;29:1605-11.

4. Ryu S, Yin FF, Rock J, Zhu J, Chu A, Kagan E. Image-guided and intensity-modulated radiosurgery for patients with spinal metastasis. Cancer. 2003;97(8):2013-8.

5. Hirsch AE, Rosenstein BS, Medich DC, Martel CB, Hirsch JA. Polymethymetacrylate and Radioisotopes in Vertebral Augmentation: An Explanation of Underlying Principles. Pain Physician. 2009;12(5):887-91.

6. Galibert $P$, Deramond $H$. Note preliminaire sur le traitement des angiomes vertebraux par vertebroplastie acrylique percutanee. Neurochirurgie. 1987;33:166-8.

7. Cardoso ER, Ashamalla H, Weng L, Mokhtar B, Ali S, Macedon M. Percutaneous tumor curettage and interstitial delivery of samarium-153 coupled with kyphoplasty for treatment of vertebral metastases. J Neurosurg Spine. 2009;10(4):336-42.

8. Viña JC. Metastasic bone pain management with radioactive isotopes. Braz arch biol technol. 2005;48(2):127-33.

9. Campos TPR, Macedo RD. Compósito Ósseo Radioativo, PI 0605721-7, Data de deposito: 21/07/2006, Carta Patente expedida em 02/05/2018. INPI-Instituto Nacional de Propriedade Industrial, http://www.inpi.gov.br

10. Donanzam BA, Campos TPR, Dalmázio I, Valente ES. Synthesis and characterization of calcium phosphate loaded with Ho-166 and Sm-153: a novel biomaterial for treatment of spine metastases. J Mater Sci Mater Med. 2013;24(12):2873-80.

11. Donanzam BA. Bioceramicas com Ho-166 e Sm-153: sintese, caracterização e avaliação dosimetrica em radiovertebroplastia. Dissertação, Programa de Ciências Técnicas Nucleares - Universidade Federal de Minas Gerais. Conselho Nacional de Desenvolvimento Científico e Tecnológico. Belo Horizonte, Brazil: 2012. p 26-65.

12. Macedo RD. Radiovertebroplastia para Tratamento de Neoplasias Malígnas óseas da Coluna Vertebral: Avaliação da proposta e da viabilidade. Dissertação, Programa de Ciências Técnicas Nucleares - Universidade Federal de Minas Gerais. Belo Horizonte, Brazil: 2005. p 20-61.

13. Gerszten PC. The Role of Minimally Invasive Techniques in the Management of Spine Tumors: Percutaneous Bone Cement Augmentation, Radiosurgery, and Microendoscopic Approaches. Orthop Clin N Am. 2007;38(3):441-50.

14. Instituto Nacional de Câncer José Alencar Gomes da Silva. Coordenação de Prevenção e Vigilância. Estimativa 2018: incidência de câncer no Brasil / Instituto Nacional de Câncer José Alencar Gomes da Silva. Coordenação de Prevenção e Vigilância. - Rio de Janeiro: INCA, 2017.128 p. ISBN 978-85-7318-361-0 (versão eletrônica). http://www.inca.gov.br/estimativa/2018/estimativa-2018. pdf. Acessado: 01/10/2018.

15. International Agency for research on Cancer, World Health Organization, Cancer Today. Globoscan 2018. http://gco.iarc.fr/today/online-analysis-pie. Acessado: 01/10/2018.

16. Cecilio AP, Takakura ET, Jumes JJ, Dos Santos JW, Herrera AC, Victorino VJ. Breast cancer in Brazil: epidemiology and treatment challenges. Breast Cancer (Dove Med Press). 2015;7:43-9.

17. Klimo P Jr, Schmidt MH. Surgical Management of Spinal Metastases. Oncologist. 2004;9(2): 188-96.

18. Weiner $S$, Wagner HD, Wagner $H$, Wagner AD, Wagner HD, Wagner $P$, et al. The material bone: structure-mechanical function relations. Annu Rev Mater Sci. 1998;28:271-98.

19. Dorozhkin SV. Calcium Orthophosphates in nature, biology and medicine. Materials (Basel). 2009:2(2):399-498.

20. De Próspero JD. Tumores ósseos (1a. ed.). São Paulo, Brasil: Roca; 2001.

21. Ong JL, Chan DC. Hydroxyapatite and their use as coatings in dental implants: a review. Crit Rev Biomed Eng. 2000;28(5-6):667-707.

22. Anselme K. Osteoblast adhesion on biomaterials. Biomaterials. 2000;21(7):667-81.

23. Dalby MJ, Silvio LD, Harper EJ, Bonfield W. Increasing hydroxyapatite incorporation into poly(methylmethacrylate) cement increases osteoblast adhesion and response. Biomaterials. 2002;23(2):569-76.

24. Harel R, Angelov L. Spine metastases: Current treatments and future directions. Eur J Cancer. 2010;46(15):2696-707.

25. Finlay IG, Mason MD, Shelley M. Radioisotopes for the palliation of metastatic bone cancer: a systematic review. Lancet Oncol. 2005;6(6):392-400.

26. Ashamalla H, Cardoso E, Macedon M, Guirguis A, Weng L, Ali S. Phase I trial of vertebral intracavitary cement and samarium (VICS): novel technique for treatment of painful vertebral metastasis. J Radiation Oncology Biol Phys. 2009;75(3):836-42.

27. Hirsch AE, Medich DC, Rosenstein BS, Martel CB, Hirsch JA. Radioisotopes and vertebral augmentation: Dosimetric analysis of a novel approach for the treatment of malignant compression fractures. Radioth Oncol. 2008;87(1):119-26.

28. Legeros RZ, Lin S, Rohanizadeh R, Mijares D, Legeros JP. Biphasic calcium phosphate bioceramics: preparation, properties and applications. J Mater Sci Mater Med. 2003;14(3):201-9.

29. Guede D, González P, Caeiro Jr. Biomechanics and Bone (I): Basic concepts and classical mechanical trials. Rev Osteoporos Metab Miner. 2013;5(1):43-50.

30. Caeiro Jr, González P, Guede D. Biomechanics and Bone (\& II): Trials in different hierarchical levels of bone and alternative tools for the determination of bone strength. Rev Osteoporos Metab Miner. 2013;5(2):99-108. 